University of Nebraska - Lincoln

DigitalCommons@University of Nebraska - Lincoln

Publications from USDA-ARS / UNL Faculty

U.S. Department of Agriculture: Agricultural

Research Service, Lincoln, Nebraska

2008

\title{
Entomopathogenic fungal endophytes
}

\author{
Fernando E. Vega \\ United States Department of Agriculture \\ Francisco Posada \\ United States Department of Agriculture \\ M. Catherine Aime \\ United States Department of Agriculture \\ Monica Pava-Ripoll \\ University of Maryland \\ Francisco Infante \\ El Colegio de la Frontera Sur
}

See next page for additional authors

Follow this and additional works at: https://digitalcommons.unl.edu/usdaarsfacpub

Part of the Agricultural Science Commons

Vega, Fernando E.; Posada, Francisco; Aime, M. Catherine; Pava-Ripoll, Monica; Infante, Francisco; and Rehner, Stephen A., "Entomopathogenic fungal endophytes" (2008). Publications from USDA-ARS / UNL Faculty. 385.

https://digitalcommons.unl.edu/usdaarsfacpub/385

This Article is brought to you for free and open access by the U.S. Department of Agriculture: Agricultural Research Service, Lincoln, Nebraska at DigitalCommons@University of Nebraska - Lincoln. It has been accepted for inclusion in Publications from USDA-ARS / UNL Faculty by an authorized administrator of DigitalCommons@University of Nebraska - Lincoln. 
Authors

Fernando E. Vega, Francisco Posada, M. Catherine Aime, Monica Pava-Ripoll, Francisco Infante, and Stephen A. Rehner 


\title{
Entomopathogenic fungal endophytes
}

\author{
Fernando E. Vega ${ }^{\mathrm{a}, *}$, Francisco Posada ${ }^{\mathrm{a}, 1}$, M. Catherine Aime ${ }^{\mathrm{d}, 2}$, Monica Pava-Ripoll $^{\mathrm{b}}$, \\ Francisco Infante $^{c}$, Stephen A. Rehner ${ }^{\mathrm{d}}$ \\ ${ }^{\text {a }}$ Sustainable Perennial Crops Laboratory, United States Department of Agriculture, Agricultural Research Service, Building 011A, BARC-W, \\ Beltsville, MD 20705, USA \\ ${ }^{\mathrm{b}}$ Department of Entomology, University of Maryland, College Park, MD 20742, USA \\ ${ }^{\mathrm{c}}$ El Colegio de la Frontera Sur (ECOSUR), Carretera Antiguo Aeropuerto Km. 2.5, Tapachula, 30700 Chiapas, Mexico \\ ${ }^{\mathrm{d}}$ Systematic Mycology and Microbiology Laboratory, United States Department of Agriculture, Agricultural Research Service, \\ Building 011A, BARC-W, Beltsville, MD 20705, USA
}

Received 19 June 2007; accepted 3 January 2008

Available online 18 January 2008

\begin{abstract}
Fungal endophytes are quite common in nature and some of them have been shown to have adverse effects against insects, nematodes, and plant pathogens.

Our research program is aimed at using fungal endophytes-mediated plant defense as a novel biological control mechanism against the coffee berry borer, the most devastating pest of coffee throughout the world. A survey of fungal endophytes in coffee plants from Hawaii, Colombia, Mexico, and Puerto Rico has revealed the presence of various genera of fungal entomopathogens, including Acremonium, Beauveria, Cladosporium, Clonostachys, and Paecilomyces. Two of these, B. bassiana and Clonostachys rosea, were tested against the coffee berry borer and were shown to be pathogenic. This paper reviews the possible mode of action of entomopathogenic fungal endophytes.

Published by Elsevier Inc.
\end{abstract}

Keywords: Acremonium; Beauveria; Biological control; Cladosporium; Clonostachys; Coffee; Endophytes; Entomopathogens; Isaria; Paecilomyces

\section{Introduction}

The term endophyte was coined by the German scientist Heinrich Anton De Bary (1884), and is used to define fungi or bacteria occurring inside plant tissues without causing any apparent symptoms in the host (Wilson, 1995). Fungal endophytes have been detected in hundreds of plants, including many important agricultural commodities such as wheat (Larran et al., 2002a), bananas (Pocasangre et al., 2000; Cao et al., 2002), soybeans (Larran et al., 2002b), and tomatoes (Larran et al., 2001). Several roles have been ascribed to fungal endophytes, including providing protection against her-

\footnotetext{
${ }^{*}$ Corresponding author. Fax: +1 3015045104.

E-mail address: Fernando.Vega@ars.usda.gov (F.E. Vega).

${ }^{1}$ Present address: Centro Nacional de Investigaciones de Café, CENICAFÉ, Chinchiná, Caldas, Colombia.

${ }^{2}$ Present address: Department of Pathology and Crop Physiology, Louisiana State University AgCenter, 302 Life Sciences Building, Baton Rouge, LA 70803, USA.
}

bivorous insects (Breen, 1994; Clement et al., 1994), plant parasitic nematodes (West et al., 1988; Elmi et al., 2000), and plant pathogens (White and Cole, 1986; Dingle and McGee, 2003; Wicklow et al., 2005).

Most reports on the effects of endophytes on insect herbivores have concentrated on turf and agronomic grasses infected with endophytic clavicipitalean fungi (Ascomycota: Hypocreales: Clavicipitaceae), which systemically infect mostly grasses in the Poaceae, Juncaceae, and Cyperaceae (Clay, 1989; Breen, 1994). For example, Neotyphodium ${ }^{3}$-infected perennial ryegrass (Lolium perenne

\footnotetext{
${ }^{3}$ Based on molecular analysis of $18 \mathrm{~S}$ rDNA sequences, Glenn et al. (1996) created the genus Neotyphodium to include the following vertically transmitted endophytic anamorphs of Epichloë on $\mathrm{C}_{3}$ grasses: Acremonium coenophialum Morgan-Jones \& W. Gams, A. typhinum Morgan-Jones \& W. Gams, A. lolii Latch, M.J. Chr. \& Samuels, A. chisosum J.F. White \& Morgan-Jones, A. starrii J.F. White \& Morgan-Jones, A. huerfanum J.F. White, G.T. Cole \& Morgan-Jones, A. uncinatum W. Gams, Petrini \& D. Schmidt, and $A$. chilensi J.F. White \& Morgan-Jones.
} 
L.) and tall fescue (Festuca arundinacea Schreb.), have been shown to have negative effects on over 40 insect species in six orders (Clement et al., 1994). Variable effects have sometimes been reported, e.g. Clement et al. (2005) reported different effects on two aphids (bird-cherry oat aphid, Rhopalosiphum padi (L.) and rose grass aphid, Metopopophium dirhodum (Walker)) and the wheat stem sawfly (Mayetiola destructor (Say)) exposed to different wild barleys infected with Neotyphodium. Fewer studies have explored this relationship in nongrass systems. However, Jallow et al. (2004) reported drastic negative effects on larvae of Helicoverpa armigera Hübner reared on tomato plants infected with a nongrass endophyte, Acremonium strictum W. Gams.

Some endophytes belong to genera that include fungal entomopathogens such as Beauveria (Ascomycota: Hypocreales). Beauveria bassiana (Balsamo) Vuillemin has been reported as an endophyte in maize (Vakili, 1990; Bing and Lewis, 1991, 1992a,b; Lomer et al., 1997; Cherry et al., 1999, 2004; Wagner and Lewis, 2000; Arnold and Lewis, 2005), potato, cotton, cocklebur, and jimsonweed (Jones, 1994), tomato (Leckie, 2002; Ownley et al., 2004), on the cocoa relative Theobroma gileri (Evans et al., 2003), in the bark of Carpinus caroliniana Walter (Bills and Polishook, 1991), in seeds and needles of Pinus monticola Dougl. ex. D. Don (Ganley and Newcombe, 2005), in opium poppy (Quesada-Moraga et al., 2006), on date palm (Gómez-Vidal et al., 2006), in bananas (Akello et al., 2007), and in coffee (Posada et al., 2007, and this paper). In addition, cocoa (Posada and Vega, 2005) and coffee seedlings (Posada and Vega, 2006) have been successfully inoculated with $B$. bassiana by depositing a spore suspension on the radicle shortly after germination. Referring to Beauveria globulifera $(=$ B. bassiana), Steinhaus (1949) wrote: "It also grows on corn and certain other plants but not so well as on insects." No specifics were given on how these observations were obtained. Fuller-Schaefer et al. (2005) have reported on the colonization of sugarbeet roots by the fungal entomopathogens B. bassiana and Metarhizium anisopliae (Metschn.) Sorokin.

Other entomopathogenic fungi have also been reported as endophytes: Verticillium (=Lecanicillium) lecanii (Zimm.) Viégas in an Araceae (Petrini, 1981); V. lecanii and Paecilomyces farinosus (Holmsk.) Brown \& Smith (=Isaria farinosa) in the bark of C. caroliniana (Bills and Polishook, 1991); Paecilomyces sp. in Musa acuminata (Cao et al., 2002) and in rice (Tian et al., 2004); and Paecilomyces varioti Bain. in mangroves (Ananda and Sridhar, 2002). Cladosporium, another genus containing insect pathogenic species (Abdel-Baky and Abdel-Salam, 2003 and references therein), has been reported as an endophyte in Festuca (An et al., 1993), in several Ericaceae (Okane et al., 1998), various grasses (Dugan and Lupien, 2002), mangroves (Suryanarayanan et al., 1998; Ananda and Sridhar, 2002), Cuscuta reflexa Roxb., Abutilon indicum (L.) Sweet and Calotropis gigantea (L.) R. Br. (Suryanarayanan et al., 2000), M. acuminata (Cao et al., 2002), wheat
(Larran et al., 2002a), oak (Gennaro et al., 2003), Ilex (Takeda et al., 2003), cacti (Suryanarayanan et al., 2005), and in apples (Cammatti-Sartori et al., 2005).

The negative effects of endophytic clavicipitalean fungi on insect herbivores have been generally ascribed to the production of fungal metabolites (Funk et al., 1983; Bush et al., 1997; Clay, 1988; Clay and Schardl, 2002), although environmental factors (Bultman and Bell, 2003) and presence of mycorrhizae and nutrients (Barker, 1987; Vicari et al., 2002) can influence the outcome of the association. The effects have also been shown to cascade to the third trophic level, e.g., parasitoids (Bultman et al., 1997). The effects of various nonclavicipitalean pine endophytes (e.g., Phyllosticta, Rhabdocline, Leptostroma, and Cryptocline) on spruce budworm (Choristoneura fumiferana (Clemens)) have also been ascribed to endophyte-produced metabolites (Clark et al., 1989; Miller et al., 2002).

The traditional mode of infection of fungal entomopathogens such as B. bassiana involves spore deposition on the insect cuticle followed by formation of a germ tube, which through enzymatic and mechanical action penetrates the cuticle (Hajek and St. Leger, 1994). Once in the hemocoel, hyphal growth causes tissue damage and nutrient depletion. Some entomopathogenic fungi are also known to produce metabolites (see Section 4) but their involvement in insect toxicosis is unclear (Gillespie and Claydon, 1989; Hajek and St. Leger, 1994).

The pioneering work on entomopathogenic endophytes was conducted using maize (Zea mays L.), B. bassiana, and the European corn borer, Ostrinia nubilalis (Hübner) as a model system. Season-long suppression of insects, measured as reduced tunneling of $O$. nubilalis, was achieved by applying B. bassiana in an aqueous (Lewis and Cossentine, 1986) or granular (Lewis and Bing, 1991) formulation on corn plants. Lewis and Bing (1991) suspected that $O$. nubilalis suppression was due to establishment of B. bassiana in the plant, based on prior reports of this phenomenon by Vakili (1990). In a subsequent paper, Bing and Lewis (1991) used granular formulations and injections of B. bassiana spore suspensions to obtain season-long suppression of $O$. nubilalis and concluded that this was due to $B$. bassiana becoming established as an endophyte in maize. Their methodology for assessing $B$. bassiana presence involved sterile techniques but does not report surface-sterilization (Bing and Lewis, 1991, 1992a), as is usually done when attempting to isolate endophytes (Arnold et al., 2001). Nevertheless, in a subsequent paper Bing and Lewis (1992b) report surface-sterilization of tissues and recovery of $B$. bassiana, thus providing evidence of an endophytic relationship. The possible mode of action for endophytic $B$. bassiana against $O$. nubilalis was not discussed in any of these studies or in subsequent studies (Lewis et al., 1996, 2001). The fact that no mycosed insects were reported (except for Bing and Lewis, 1993 - see Section 4) suggests that the reduced tunneling reported in all the papers (Lewis and Cossentine, 1986; Lewis and Bing, 1991; Bing and Lewis, 1991; Bing and Lewis, 1992a,b; 
Lewis et al., 1996) could be a result of feeding deterrence or antibiosis. Bing and Lewis (1993) report that out of $1623 O$. nubilalis larvae sampled from control maize plants and maize plants inoculated with $B$. bassiana, 1556 were negative for $B$. bassiana, based on mycosis. It is not clear how the insects that exhibited mycosis became infected since no conidia were observed internally in the plants (Wagner and Lewis, 2000) thus indicating that the infective propagulum was not available to infect insects. Conidial formation within the host plant was not found for Neotyphodium endophytes in grasses either (Clay, 1989).

Wagner and Lewis (2000) have shown that, following conidia germination and germ tube development, B. bassiana enters maize tissues directly through the plant cuticle. Subsequent hyphal growth occurs within the apoplast, but only occasionally extending into the xylem elements. The introduction of endophytic B. bassiana in maize is compatible with other pest management strategies. It has been shown that endophytic $B$. bassiana is compatible with both $B$. thuringiensis $(\mathrm{Bt})$ and carbofuran applications used to suppress $O$. nubilalis (Lewis et al., 1996). Use of Bt transgenic corn did not have any detectable effect on the establishment of B. bassiana as a corn endophyte (Lewis et al., 2001). Endophytic B. bassiana caused no mortality to Coleomegilla maculata De Geer, a predator of $O$. nubilalis eggs and larvae (Pingel and Lewis, 1996).

As part of a 3-year survey, we have identified hundreds of fungal endophytes isolated from various tissues of the coffee plant in several countries. In this paper we report the presence of 16 different coffee endophytes belonging to five genera of known entomopathogenic fungi: Acremonium, Beauveria, Cladosporium, Clonostachys, and Paecilomyces. We also report on the pathogenicity of two of these (B. bassiana and Clonostachys rosea) against the most devastating pest of coffee throughout the world, the coffee berry borer (Hypothenemus hampei (Ferrari), Coleoptera: Curculionidae), and speculate on the possible mode of action of entomopathogenic fungal endophytes.

\section{Materials and methods}

\subsection{Endophyte isolation}

Coffee (Coffea arabica L.) tissues, including leaves, stems, roots, and various parts of the berry ${ }^{4}$ (peduncle, epicarp (skin of the fruit), crown, and seeds) were surface-disinfected by submersing in $0.5 \%$ sodium hypochlorite for $2 \mathrm{~min}$, followed by $2 \mathrm{~min}$ in $70 \%$ ethanol and rinsing in sterile distilled water (Arnold et al., 2001). The tissues were dried on sterile paper towels and the edges were cut to remove dead tissue ensuing from the disinfection process, resulting in $4-9 \mathrm{~mm}^{2}$ sections, six of which were placed in each of two petri dishes containing yeast maltose agar (YMA; Sigma-Aldrich Co., St. Louis,

\footnotetext{
${ }^{4}$ Even though the correct botanical term is drupe, it is commonly referred to as a berry.
}

MO) to which a $0.1 \%$ stock antibiotic solution was added. The antibiotic stock consisted of $0.02 \mathrm{~g}$ of each of three antibiotics (tetracycline, streptomycin, and penicillin) dissolved in $10 \mathrm{ml}$ sterile distilled water, followed by filtersterilization through a $0.2-\mu \mathrm{m}$ filter (Nalgene Disposable Filterware, Nalge Nunc International Rochester, NY); from this, $1 \mathrm{ml}$ was added to each liter of medium. Any fungal growth was subcultured on individual plates containing YMA plus antibiotics for subsequent identification. Voucher cultures are maintained at the Sustainable Perennial Crops Laboratory (USDA, ARS) in Beltsville, Maryland (Table 1).

\subsection{Endophyte DNA extraction}

All endophyte isolates were grown in potato dextrose broth (Difco, Sparks, MD) at $125 \mathrm{rpm}$ on an Innova 4000 Incubator Shaker (New Brunswick Scientific Co., Inc., Edison, $\mathrm{NJ}$ ) at $25^{\circ} \mathrm{C}$. Tissue was then harvested, lyophilized, and stored at $-80^{\circ} \mathrm{C}$. For DNA extraction, approximately $50 \mathrm{mg}$ lyophilized mycelium was placed in a $2 \mathrm{ml}$ microcentrifuge tube with ca. $0.2 \mathrm{ml} 1.0$ zirconiaglass beads (Cat \# 1107911-0z, BIOSPEC, Bartlesville, OK). The mycelium was crushed with a plastic pestle and further ground in a FastPrep-120 sample grinder (Q-BIOgene, Irvine, CA) for $3 \mathrm{~s}$ at the maximum speed setting of 6 . The powdered mycelium was suspended in $700 \mu$ l detergent solution $(2 \mathrm{M} \mathrm{NaCl}, 0.4 \% \mathrm{w} / \mathrm{v}$ deoxycholic acid-sodium salt, $1 \% \mathrm{w} / \mathrm{v}$ polyoxyethylene 20 cetyl ether) and then agitated for $14 \mathrm{~s}$ in the Fast-Prep at maximum speed. Vials were incubated $5 \mathrm{~min}$ at $55^{\circ} \mathrm{C}$ in a heat block and then centrifuged at 10,600 rpm for 5 min followed by emulsion with $700 \mu \mathrm{l}$ chloroform/isopropyl and centrifugation at $10,600 \mathrm{rpm}$ for $5 \mathrm{~min}$. The aqueous phase was transferred to a clean tube to which an equal volume of $6 \mathrm{M}$ guanidinium thiocyanate was added. Fifteen microliters of silica powder were gently mixed with the solution while incubating at room temperature for $5 \mathrm{~min}$, followed by $3 \mathrm{~s}$ centrifugation, after which the supernatant was discarded. The glass powder was rinsed twice by suspending in $750 \mu \mathrm{l}$ ethanol buffer $(10 \mathrm{mM}$ Tris- $\mathrm{HCl}, \mathrm{pH} 8.0,0.1 \mathrm{mM}$ EDTA, 50\% ethanol) with a disposable transfer pipette, then collected by centrifugation and the supernatant discarded, and the glass powder pellet was dried on a heat block at $55^{\circ} \mathrm{C}$ for $5-10 \mathrm{~min}$. The glass powder was rehydrated with $105 \mu 1$ ultra-pure water and the genomic DNA eluted by incubating on a heat block at $55^{\circ} \mathrm{C}$ for $5-10 \mathrm{~min}$. Following vortexing and centrifugation, $100 \mu \mathrm{l}$ of the aqueous supernatant was transferred to a clean tube.

\subsection{Endophyte DNA sequencing and analyses}

The internal transcribed spacer region (ITS) of the nuclear rDNA repeat was sequenced for each isolate; primers ITS1-F (fungal-specific) (Gardes and Bruns, 1993) and ITS4 (White et al., 1990) were used for both amplification 
Table 1

Fungal endophytes from entomopathogenic genera isolated from various coffee tissues collected in Colombia, Hawaii, Mexico, and Puerto Rico

\begin{tabular}{|c|c|c|c|c|c|}
\hline SPCL\# & Fungal endophyte & GenBank & Tissue & Collection site and date & GPS \\
\hline 03047 & Acremonium alternatum & $\mathrm{n} / \mathrm{a}$ & Epicarp & COLOMBIA. Caldas, Chinchiná, December, 2003 & $\mathrm{~N} 5^{\circ} 00^{\prime}, \mathrm{W} 75^{\circ} 36^{\prime}$ \\
\hline 03039 & Acremonium sp. & DQ287230 & Root & $\begin{array}{l}\text { USA. Hawaii, Kona, Kona Experimental Station, } \\
\text { September } 2003\end{array}$ & $\begin{array}{l}\text { N } 19^{\circ} 32.048^{\prime}, \mathrm{W} \\
155^{\circ} 55.494^{\prime}\end{array}$ \\
\hline 03032 & Beauveria bassiana & DQ287236 & Seed & COLOMBIA. Caldas, Chinchiná, September 2003 & $\mathrm{~N} 5^{\circ} 00^{\prime}, \mathrm{W} 75^{\circ} 36^{\prime}$ \\
\hline 03042 & Beauveria bassiana & DQ287232 & Epicarp & COLOMBIA. Caldas, Chinchiná, September 2003 & $\mathrm{~N} 5^{\circ} 00^{\prime}, \mathrm{W} 75^{\circ} 36^{\prime}$ \\
\hline 03043 & Beauveria bassiana & DQ287231 & Peduncle & COLOMBIA. Caldas, Chinchiná, September 2003 & $\mathrm{~N} 5^{\circ} 00^{\prime}, \mathrm{W} 75^{\circ} 36^{\prime}$ \\
\hline 03044 & Beauveria bassiana & DQ287233 & Crown & COLOMBIA. Caldas, Chinchiná, September 2003 & $\mathrm{~N} 5^{\circ} 00^{\prime}, \mathrm{W} 75^{\circ} 36^{\prime}$ \\
\hline 02002 & $\begin{array}{l}\text { Cladosporium } \mathrm{cf} . \\
\text { cladosporioides }\end{array}$ & DQ299297 & Leaves & PUERTO RICO. Adjuntas, June 2002 & $\begin{array}{l}\text { N } 18^{\circ} 10.959^{\prime}, \mathrm{W} \\
066^{\circ} 51.029^{\prime}\end{array}$ \\
\hline 04003 & $\begin{array}{l}\text { Cladosporium } \mathrm{cf} . \\
\text { cladosporioides }\end{array}$ & DQ299302 & Leaves & $\begin{array}{l}\text { USA. Hawaii, Kona, Kona Experimental Station, } \\
\text { March } 2004\end{array}$ & $\begin{array}{l}\text { N } 19^{\circ} 32.048^{\prime}, \mathrm{W} \\
155^{\circ} 55.494^{\prime}\end{array}$ \\
\hline 04001 & $\begin{array}{l}\text { Cladosporium } \mathrm{cf} . \\
\text { sphaerospermum }\end{array}$ & DQ299296 & Leaves & $\begin{array}{l}\text { USA. Maryland, Beltsville (Behnke's Nurseries), } \\
\text { January } 2004\end{array}$ & $\begin{array}{l}\text { N } 39^{\circ} 02.424^{\prime}, \mathrm{W} \\
076^{\circ} 54.347^{\prime}\end{array}$ \\
\hline 03073 & Cladosporium sp. 1 & DQ299303 & Peduncle & $\begin{array}{l}\text { USA. Hawaii, Kona, Kona Experimental Station, } \\
\text { November } 2003\end{array}$ & $\begin{array}{l}\text { N } 19^{\circ} 32.048^{\prime}, \mathrm{W} \\
155^{\circ} 55.494^{\prime}\end{array}$ \\
\hline 04002 & $\begin{array}{l}\text { Cladosporium sp. } 2 \\
\text { (C. cladosporioides complex) }\end{array}$ & DQ299301 & Seeds & $\begin{array}{l}\text { USA. Hawaii, Kona, Kona Experimental Station, } \\
\text { March } 2004\end{array}$ & $\begin{array}{l}\text { N } 19^{\circ} 32.048^{\prime}, \mathrm{W} \\
155^{\circ} 55.494^{\prime}\end{array}$ \\
\hline 03071 & $\begin{array}{l}\text { Cladosporium sp. } 3 \\
\text { (C. cladosporioides complex) }\end{array}$ & DQ299299 & Leaves & COLOMBIA. Caldas, Chinchiná, July 2003 & $\mathrm{~N} 5^{\circ} 00^{\prime}, \mathrm{W} 75^{\circ} 36^{\prime}$ \\
\hline 03070 & $\begin{array}{l}\text { Cladosporium sp. } 4 \\
\text { (C. cladosporioides complex) }\end{array}$ & DQ299298 & Epicarp & COLOMBIA. Caldas, Chinchiná, July 2003 & $\mathrm{~N} 5^{\circ} 00^{\prime}, \mathrm{W} 75^{\circ} 36^{\prime}$ \\
\hline 03072 & $\begin{array}{l}\text { Cladosporium sp. } 4 \\
\text { (C. cladosporioides complex) }\end{array}$ & DQ299300 & Crown & COLOMBIA. Caldas, Chinchiná, July 2003 & $\mathrm{~N} 5^{\circ} 00^{\prime}, \mathrm{W} 75^{\circ} 36^{\prime}$ \\
\hline 03062 & Clonostachys rosea & DQ287243 & Leaves & COLOMBIA. Caldas, Chinchiná, September 2003 & $\mathrm{~N} 5^{\circ} 00^{\prime}, \mathrm{W} 75^{\circ} 36^{\prime}$ \\
\hline 03076 & Paecilomyces cf. fumosoroseus & DQ287244 & Crown & PUERTO RICO. Adjuntas, June 2003 & $\begin{array}{l}\text { N } 18^{\circ} 10.226^{\prime}, \mathrm{W} 066^{\circ} \\
47.869^{\prime}\end{array}$ \\
\hline 03066 & Paecilomyces cf. javanicus & DQ287245 & Peduncle & COLOMBIA. Caldas, Chinchiná, September 2003 & $\mathrm{~N} 5^{\circ} 00^{\prime}, \mathrm{W} 75^{\circ} 36^{\prime}$ \\
\hline 03067 & $\begin{array}{l}\text { Paecilomyces sp. } 1 \text { (near } P \text {. } \\
\text { inflatus) }\end{array}$ & DQ287246 & Epicarp & $\begin{array}{l}\text { MEXICO. Chiapas, Cacahoatán, Rancho El Paraíso, } \\
\text { February } 2003\end{array}$ & $\begin{array}{l}\mathrm{N} 15^{\circ} 00^{\prime} 27.6^{\prime \prime}, \mathrm{W} \\
92^{\circ} 09^{\prime} 51.2^{\prime \prime}\end{array}$ \\
\hline 03069 & $\begin{array}{l}\text { Paecilomyces sp. } 2 \text { (near } P . \\
\text { lilacinus) }\end{array}$ & DQ287248 & $\begin{array}{l}\text { Seedling - } \\
\text { Root }\end{array}$ & $\begin{array}{l}\text { USA. Hawaii, Kona Experimental Station, September } \\
2003\end{array}$ & $\begin{array}{l}\text { N } 19^{\circ} 32.048^{\prime}, \mathrm{W} \\
155^{\circ} 55.494^{\prime}\end{array}$ \\
\hline
\end{tabular}

and sequencing. PCRs were performed in $25 \mu 1$ reaction volumes with $12.5 \mu \mathrm{l}$ of PCR Master Mix (Promega Corp., Madison, WI), $1.25 \mu \mathrm{l}$ each of $10 \mu \mathrm{M}$ primers, and $10 \mu \mathrm{l}$ of diluted (10- to 100-fold) DNA template. Amplification was achieved with an initial denaturation step of $5 \mathrm{~min}$ at $94{ }^{\circ} \mathrm{C} ; 35$ cycles of $30 \mathrm{~s}$ at $94{ }^{\circ} \mathrm{C}, 45 \mathrm{~s}$ at $50{ }^{\circ} \mathrm{C}$, and $45 \mathrm{~s}$ at $72{ }^{\circ} \mathrm{C}$; and a final extension of $7 \mathrm{~min}$ at $72{ }^{\circ} \mathrm{C}$. The PCR products were cleaned with Montage PCR Centrifugal Filter Devices (Millipore Corp., Billerica, MA) according to the manufacturer's protocol. Cleaned PCR products were sequenced with BigDye Terminator sequencing enzyme v.3.1 (Applied Biosystems, Foster City, CA) in the reaction: $2 \mu \mathrm{l}$ of diluted BigDye in a 1:3 dilution of BigDye:dilution buffer (400 mM Tris, pH 8.0, $10 \mathrm{mM} \mathrm{MgCl}_{2}$ ); $0.3 \mu \mathrm{l}$ of $10 \mu \mathrm{M}$ primer; $10-20 \mathrm{ng}$ of cleaned PCR template; and $\mathrm{H}_{2} \mathrm{O}$ to $5 \mu \mathrm{l}$ total reaction volume. Cycle sequencing parameters consisted of a $2 \mathrm{~min}$ denaturation step at $94{ }^{\circ} \mathrm{C}$, then 35 cycles of $94{ }^{\circ} \mathrm{C}$ for $39 \mathrm{~s}, 50{ }^{\circ} \mathrm{C}$ for $15 \mathrm{~s}$, and $60{ }^{\circ} \mathrm{C}$ for $4 \mathrm{~min}$. Sequencing reactions were cleaned by ethanol precipitation and sequenced on an ABI 3100 Genetic Analyzer (Applied Biosystems, Foster City, CA). Sequencing reactions were edited and contiguous sequences for each isolate were assembled in Sequencher v.4.1.4 (Gene Codes Corp., Ann Arbor, MI). DNA sequences have been deposited in GenBank (Table 1).

\subsection{Identification of isolates}

Initial identification of isolates was obtained by BLAST analysis (http://www.ncbi.nlm.nih.gov/BLAST/). Morphological identification for each isolate was then confirmed with the aid of the following keys and manuals: Paecilomyces isolates were identified to genus and species based on Samson (1974) and further confirmed by phylogenetic analysis as outlined by Rehner and Buckley (2005); Beauveria isolates were identified to genus based on Humber (1997); Cladosporium and Acremonium were identified to genus using St.-Germain and Summerbell (1996) and Barnett and Hunter (1998); and Clonostachys rosea and Acremonium alternatum were identified to species by W. Gams (CBS, The Netherlands).

\subsection{Insect bioassays}

Adult coffee berry borers, less than 3-months-old, were reared on artificial diet (Villacorta, 1985; Portilla, 2000). Prior to initiating the bioassay, adult insects were washed in a $0.5 \%$ sodium hypochlorite solution with $0.01 \%$ Triton X-100 (Sigma Chemical Co., St. Louis, MO) and gently shaken for $10 \mathrm{~min}$, then rinsed three times in sterile distilled water and dried in a container lined with sterile 
paper towels. This was done to eliminate any fungi present on the insect cuticle.

Endophytic single spore isolates of B. bassiana (Sustainable Perennial Crops Laboratory Culture Collection $=$ SPCL 03047) and Clonostachys rosea $($ SPCL 03062) stored in $10 \%$ glycerol at $-80{ }^{\circ} \mathrm{C}$ were grown in Sabouraud's dextrose agar (Difco, Sparks, MD) and YMA, respectively, and incubated at $25^{\circ} \mathrm{C}$. All cultures were less than 30-daysold when used in the bioassays. Spores were collected with a spatula and placed in sterile tubes containing $10 \mathrm{ml}$ of sterile distilled water plus $0.1 \%$ Triton X-100 (Sigma Chemical Co., St. Louis, MO). The concentrations were adjusted to $1 \times 10^{7}$ spores per ml using a hemacytometer.

Spore germination was determined by plating a $1 \times 10^{-3}$ spore suspension on $2.5 \%$ Noble agar (Difco, Sparks, MD) incubated at $27{ }^{\circ} \mathrm{C}$. Germination was assessed at $24 \mathrm{~h}$ and $48 \mathrm{~h}$ by taking 3 samples of the media and placing them individually on slides, followed by counting 100 spores. Spores were deemed to have germinated when the longitude of the germ tube was longer than half the diameter of the spores.

The coffee berry borer adults assigned to the treatments were dipped in a 10-ml spore suspension with $1 \times 10^{7}$ spores per ml plus $0.1 \%$ Triton $\mathrm{X}-100$; control insects were dipped in sterile distilled water plus $0.1 \%$ Triton X-100. Insects were gently shaken for 2 min while dipped in their respective treatments and then placed in a sterile container from which they were taken individually with a sterile paintbrush and placed in a vial containing two pieces of sterile Whatman \#1 filter paper $(2.1 \mathrm{~cm}$ diam; Whatman Inc., Clifton, NJ) moistened with $100 \mu$ of sterile distilled water. The vials were closed with caps and sterile distilled water was added to the filter paper as needed. All treatments were incubated in the dark at $25^{\circ} \mathrm{C}$ in a growth chamber (Model E-36 L, Percival Scientific, Inc., Boone, IA). Insect mortality was assessed on a daily basis.

The experiment was conducted as a completely randomized design with each isolate replicated 40 times and beetles individually placed in separate vials. For controls, two sets of 40 insects were used, each insect in an individual vial. For statistical purposes, mortality was analyzed by grouping the experimental units as 4 replicates with 10 insects. Percent insect mortality was analyzed using proc mixed (SAS Institute, Inc., 2001). Average insect survival time was analyzed using survival analysis, which includes all individuals (JMP SAS, 2000), in contrast to $\mathrm{LT}_{50}$, which only includes those that have died.

Our assessments of the saprotrophic phase were based on the time it takes for four events to occur after the insect has died: (1) number of days after death until mycelium is first observed on the insect corpse; (2) number of days from the first formation of mycelium until the mycelium has reached a maximum coverage of the corpse; (3) time between maximum mycelium coverage until conidiophores are first seen; and (4) time elapsed from first observation of conidiophores until conidia begin to discharge. Observations were made every $24 \mathrm{~h}$ and in cases where a certain event seemed to be well advanced at the time of the obser- vation, indicating it had been achieved shortly after the previous observation, the time to that specific event was back-estimated $12 \mathrm{~h}$. The data for each event were analyzed using proc mixed (SAS Institute, Inc., 2001).

Spore production was determined by randomly selecting 5 beetles (out of 40) within each treatment for which there was sporulation. Each beetle was washed with $5 \mathrm{ml}$ of sterile distilled water with $0.1 \%$ Triton X-100 and sonicated for $1 \mathrm{~min}$. A diluted spore suspension was placed in three different hemacytometers and eight 16-square grids were counted for each one. The data were analyzed using a one-way analysis of variance (ANOVA proc mixed; SAS Institute, Inc., 2001). In all tests, $P<0.05$ was considered significant.

\section{Results}

Isolation of endophytic fungi from coffee tissues collected in Hawaii, Colombia, Puerto Rico, and Mexico revealed the presence of 16 species in five genera of entomopathogenic fungi in coffee plants (Table 1). These were: Acremonium sp. from roots collected in Hawaii; Acremonium alternatum Link: Fries from the epicarp of coffee berries collected in Colombia; Beauveria bassiana from the peduncle, epicarp, crown, and seed of coffee berries from Colombia; Beauveria brongniartii (Sacc.) Petch from the crown of a coffee berry collected in Hawaii; Cladosporium cf. sphaerospermum, Cladosporium. sp. \#1, Cladosporium cf. cladosporioides, and Cladosporium sp. 2-4 (in the C. cladosporioides complex) from leaves collected in Puerto Rico, Colombia, Hawaii, and Maryland (a local plant nursery that sells coffee seedlings); from the epicarp and crown of berries from Colombia and from the peduncle and seeds from berries collected in Hawaii; Clonostachys rosea (Link) Schroers et al. from leaves collected in Colombia; Paecilomyces cf. fumosoroseus ${ }^{5}$ from the crown of berries in Puerto Rico; Paecilomyces cf. javanicus from peduncles collected in Colombia; a Paecilomyces sp. (near P. inflatus) from the epicarp of berries collected in Mexico; and another Paecilomyces sp. (near P. lilacinus) from roots of seedlings from Hawaii (Table 1). These fungi span three different orders within the phylum Ascomycota: Mycosphaerellales (Cladosporium spp. in the Mycosphaerellaceae); Eurotiales (Paecilomyces spp. in the Trichocomaceae); Hypocreales (Clonostachys rosea in the Bionectriaceae; Beauveria bassiana in the Cordycipitaceae; and Acremonium spp. in the Nectriaceae).

Percentage of conidia germinating was $83 \%$ for the endophytic B. bassiana (at $48 \mathrm{~h}$ ) and $83 \%$ for $C$. rosea (at $24 \mathrm{~h})$. Cumulative mortality, 21 days post-inoculation, was $100 \%$ for B. bassiana and $82.5 \%$ for C. rosea (Fig. 1). There were significant differences in mortality between fungi-treated insects $(\mathrm{df}=3,15, f=1809, P<0.0001)$ and the control. No fungal infection was ever observed in any

\footnotetext{
${ }^{5}$ The taxonomy for Paecilomyces has changed recently and the isolate originally identified as Paecilomyces cf. fumosoroseus has since been transferred to Isaria fumosorosea (Hypocreales: Cordycipitaceae) (Humber, 2007).
} 


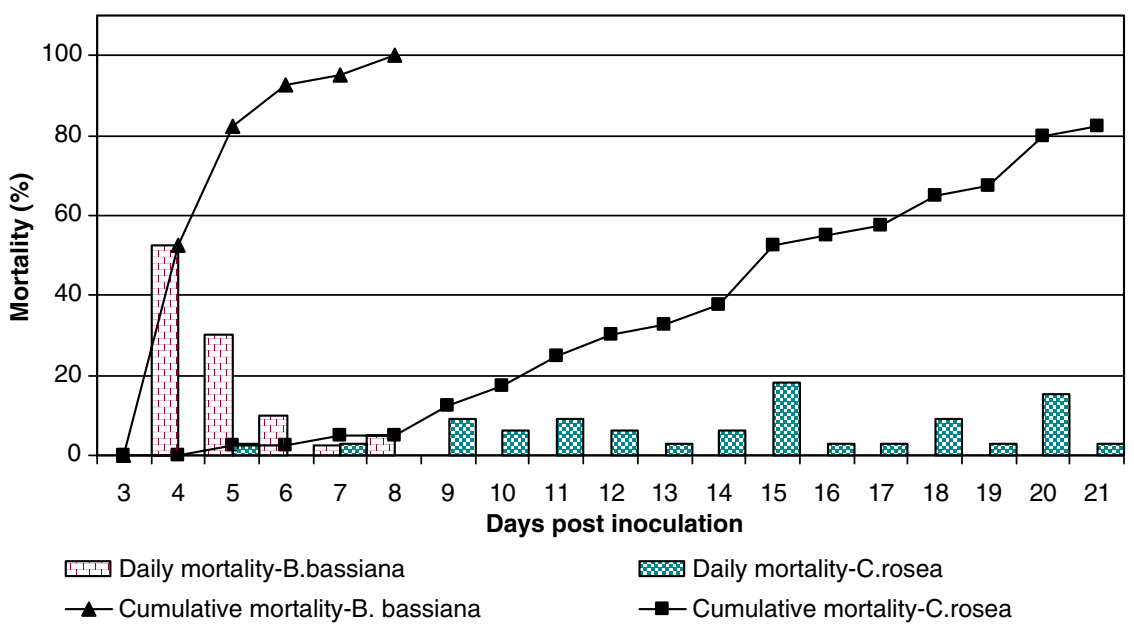

Fig. 1. Daily and cumulative mortality distribution (\%) for adult coffee berry borers inoculated with a $1 \times 10^{7}$ spores per ml of endophytic Beauveria bassiana (SPCL 03047) or Clonostachys rosea (SPCL 03062) spore suspension.

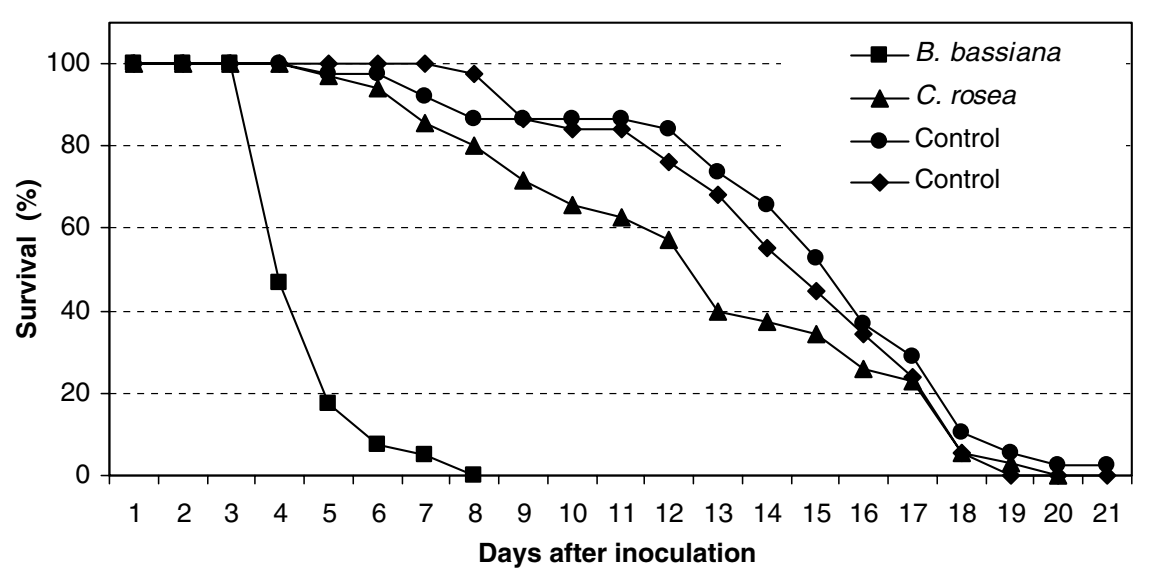

Fig. 2. Average survival time for adult coffee berry borers inoculated with a $1 \times 10^{7}$ spores per ml of endophytic Beauveria bassiana (SPCL 03047) or Clonostachys rosea (SPCL 03062) spore suspension.

of the controls. The average survival time for insects treated with $B$. bassiana was $4.8 \pm 0.2$ days and $14.7 \pm 0.75$ days for $C$. rosea-treated insects, compared to $15.0 \pm 0.6$ for the controls (Fig. 2). Spore production per insect was $1.2 \times 10^{7} \pm 4.0 \times 10^{6}$ for $B$. bassiana and $3.6 \times 10^{6} \pm$ $9.3 \times 10^{5}$ for $C$. rosea. The life cycle (time from inoculation to spore discharge from the insect corpse) for $B$. bassiana was $9.9 \pm 0.2$ days (Fig. 3) while C. rosea completed its life cycle in $16.4 \pm 1.1$ days (Fig. 4).

\section{Discussion}

We have identified several endophytic fungi in coffee tissues that belong to genera containing entomopathogenic fungi (Table 1). Bioassays conducted with two of the isolates, B. bassiana and C. rosea, indicate that these are pathogenic to the coffee berry borer. Even though the role that these endophytic fungi might have against insects is not clear, we can speculate on their mode of action.

Research on B. bassiana as a maize endophyte suggests that the reduced tunneling of $O$. nubilalis could be due to the presence of fungal metabolites that cause feeding deterrence or antibiosis. This is based on the overwhelming absence of $B$. bassiana infection within $O$. nubilalis individuals that feed on endophytic plants (Lewis and Bing, 1991; Bing and Lewis, 1991, 1992a,b), despite a report by Bing and Lewis (1993) that showed $2.5 \%$ mycosis on insects feeding on endophytic plants (and 1.7\% mycoses on insects feeding on plants with no B. bassiana). The lack of B. bassiana conidia in endophytic plants (Wagner and Lewis, 2000) also suggests a mode of action involving feeding deterrence or antibiosis rather than direct fungal infection. If spores were present, per os infection could be possible (Gabriel, 1959; Broome et al., 1976; Bell and Hamalle, 1980) although it could be difficult to discern between actual per os infection and infection due to spores coming in contact with the insect cuticle (Allee et al., 1990; Inglis et al., 1996). A study by Cherry et al. $(1999,2004)$ in Africa supports the feeding deterrence/antibiosis hypothesis. They studied B. bassiana endophytism in Africa when attempting to control the maize stem borer (Sesamia calamistis Hampson) by treating maize seeds with dry B. bassiana conidia, 


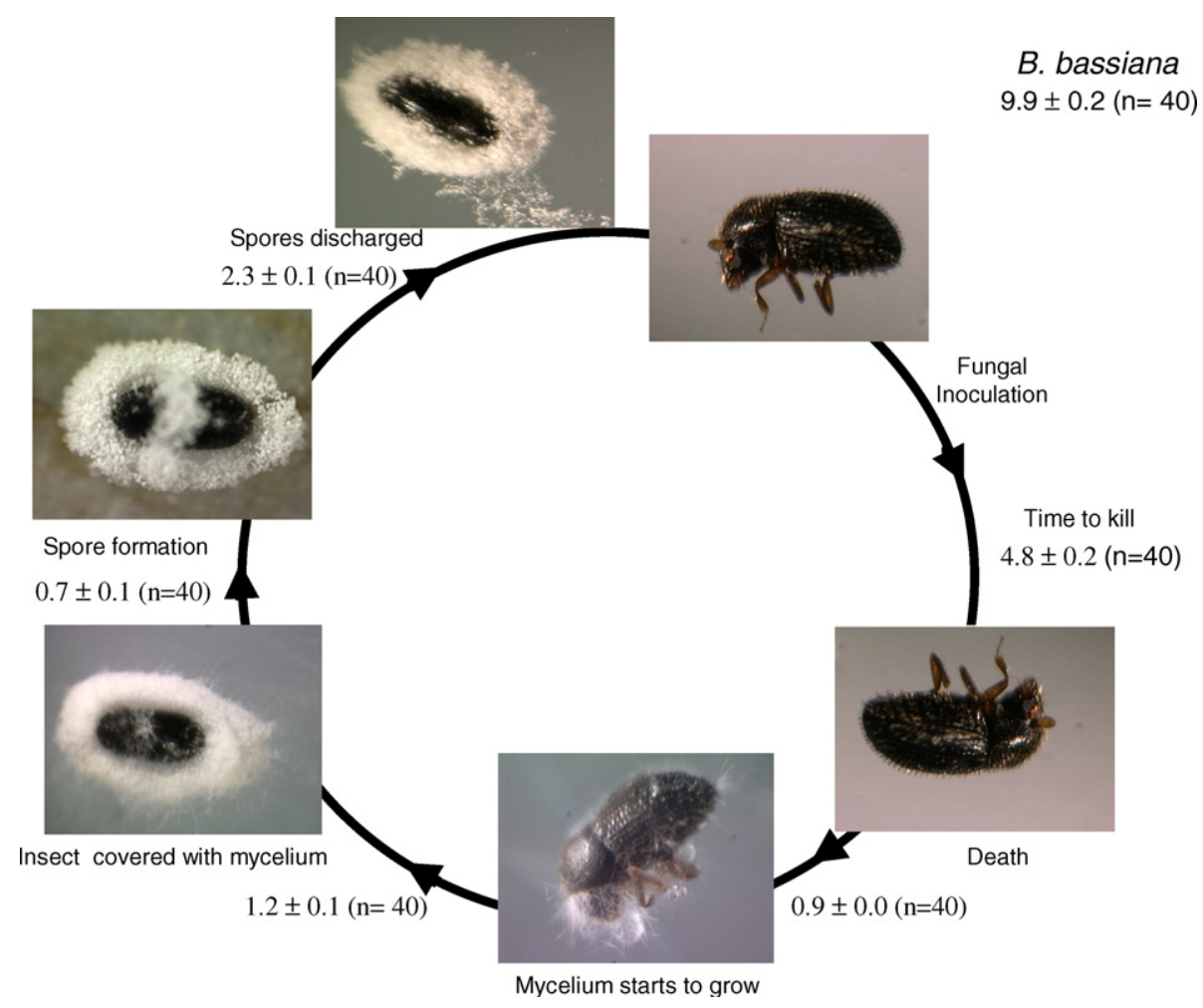

Fig. 3. Life cycle (days; mean \pm SE) for adult coffee berry borers inoculated with a $1 \times 10^{7}$ spores per ml of endophytic Beauveria bassiana (SPCL 03047) spore suspension. The assessments were made daily after fungal inoculation and included days to (1) insect death; (2) mycelium starting to grow; (3) insect covered with mycelium; (4) spore formation; and (5) spore discharge.

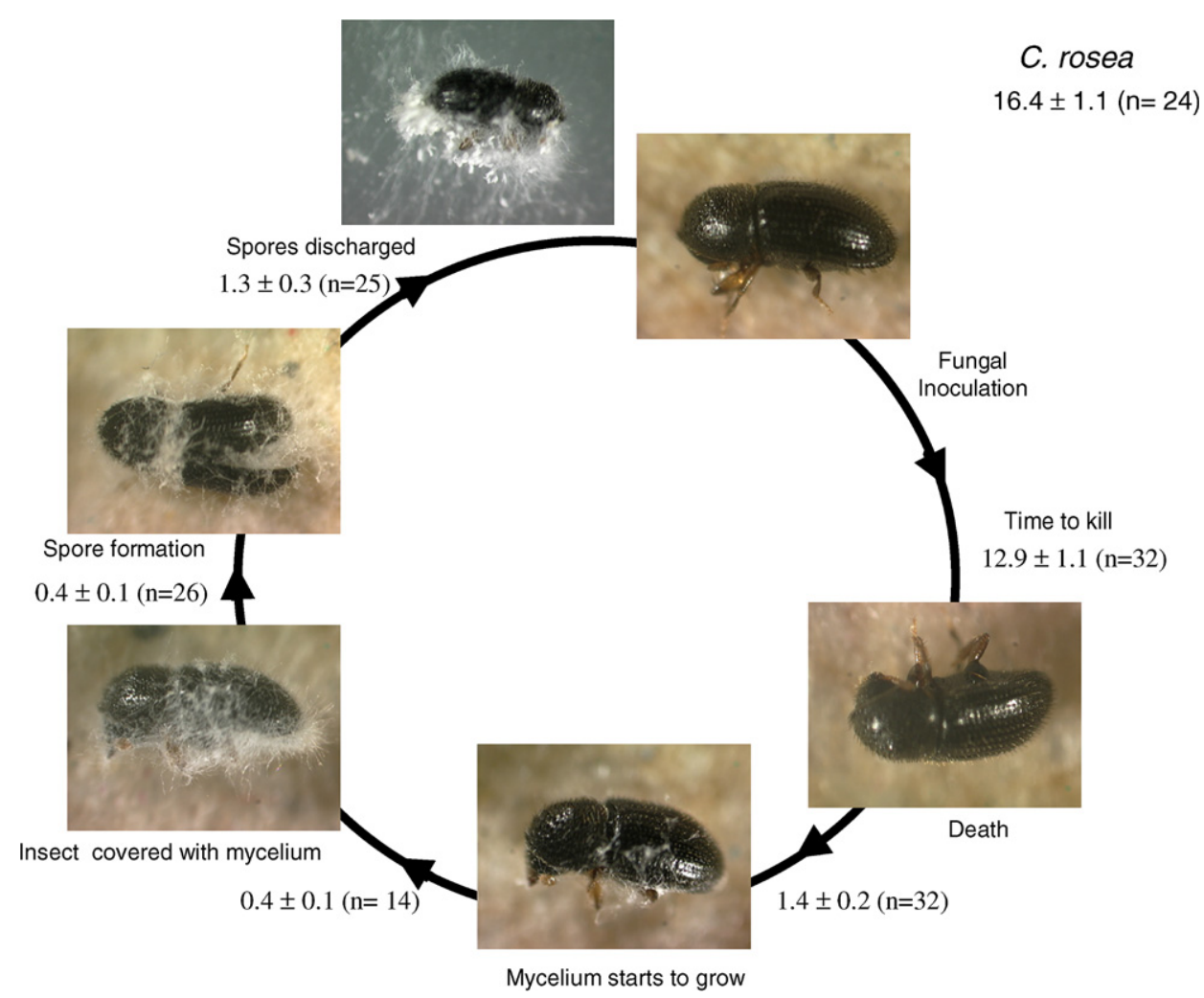

Fig. 4. Life cycle (days; mean \pm SE) for adult coffee berry borers inoculated with a $1 \times 10^{7}$ spores per ml of endophytic Clonostachys rosea (SPCL 03062) spore suspension. The assessments were made daily after fungal inoculation and included days to (1) insect death; (2) mycelium starting to grow; (3) insect covered with mycelium; (4) spore formation; and (5) spore discharge. 
by spraying conidial suspensions in the leaf axils, and by injecting conidial suspension in the stem. Lomer et al. (1997) had previously reported that B. bassiana could be isolated as an endophyte in maize in Africa, and Cherry et al. $(1999,2004)$ showed reduced tunneling of the stem borer in plants treated with $B$. bassiana, even though no attempt was made to reisolate the fungus. In plants injected with $B$. bassiana, larvae were lighter than in the control plants suggesting they did not feed as much, supporting the deterrence/antibiosis hypothesis. None of the dead larvae exhibited symptoms of mycosis.

Beauveria spp. produce several metabolites, including bassianin, beauvericin, bassianolide, beauveriolide, bassiacridin, oosporein, and tenellin (Vining et al., 1962; Hamill et al., 1969; Suzuki et al., 1977; Roberts, 1981; Jeffs and Khachatourians, 1997; Strasser et al., 2000; QuesadaMoraga and Vey, 2004). Beauvericin is toxic to Culex pipiens L., rupturing the midgut epithelium and dissolving the ribosomes (Žižka and Weiser, 1993), and to Aedes aegypti (L.) and Calliphora erythrocephala Meigen (Grove and Pople, 1962). In contrast, Champlin and Grula (1979) reported that beauvericin was not toxic to Helicoverpa zea Boddie and that bassianolide caused temporary atony. Paecilomyces fumosoroseus (Wize) Brown \& Smith (=Isaria fumosorosea) has also been reported to produce beauvericin (Bernardini et al., 1975) and beauverolides (Jegorov et al., 1994), and Verticillium lecanii (=Lecanicillium lecanii) also produces bassionalide (Suzuki et al., 1977). Other entomopathogenic fungi also produce metabolites, e.g., Isaria spp. Pers.: Fr. produces isariin (Briggs et al., 1966); Hirsutella thompsonii Fisher produces phomalactone (Krasnoff and Gupta, 1994) and hirsutellin A (Mazet et al., 1995), which are known to have ribonuclease activity (Liu et al., 1996) and to be toxic to the citrus rust mite (Omoto and McCoy, 1998); Oospora destructor (Metschn.) Delacr. produces destruxins (Kodaira, 1962) that are known to be toxic to Delia antiqua (Meigen) (Poprawski et al., 1985); Metarhizium spp. produces destruxins and cytochalasins (Roberts, 1981); Paecilomyces tenuipes (Peck) Samson (=Isaria tenuipes) produces tenuipesine (Kikuchi et al., 2004); Akanthomyces gracilis Samson and Evans produces akanthomycin (Wagenar et al., 2002); Cordyceps pseudomilitaris Hywel-Jones \& Sivichai produces coryanhidrides (Isaka et al., 2000); Tolypocladium spp. produce efrapeptins (Krasnoff and Gupta, 1992); Aschersonia aleyrodis Webber produces destruxins and homodestruxins (Krasnoff et al., 1996); and Aschersonia tubulata produces dustanin (Boonphong et al., 2001). For a review on metabolites produced by entomopathogenic fungi, see Roberts (1981), Gillespie and Claydon (1989), and Strasser et al. (2000). Nevertheless, it is possible that production of these metabolites, in addition to possibly having a function against insects, might also act against other fungi or bacteria. For example, Lee et al. (2005) surveyed 47 entomopathogenic fungi and found that $81 \%$ produced anti-Bacillus compounds, while $64 \%$ produced anti-Staphylococcus compounds. Similarly, antibacterial effects have been reported for oosporein (Vin- ing et al., 1962; Wainwright et al., 1986) and beauvericin (Castlebury et al., 1999). Metabolites from other fungi have also been reported to act against entomopathogenic fungi. For example, a Penicillium urticae Bainier metabolite known as patulin has been shown to inhibit growth and germination of B. bassiana (Shields et al., 1981).

We have isolated several fungal endophytes belonging to genera that include fungal entomopathogens. It would be interesting to determine how these compare with nonendophytic isolates. This type of survey for entomopathogenic fungal endophytes might reveal new isolates with potential in biocontrol against pests of agronomic importance. If fungal entomopathogens occurring as endophytes exert their action against insects via the production of metabolites, then they would be analogous to the mode of action reported for clavicipitaceous fungi (see Section 1). This raises the issue of whether inoculation of agronomically important plants with fungal entomopathogens might create a problem by producing metabolites that could potentially enter the food chain. This is an area in need of detailed studies.

\section{Acknowledgments}

Special thanks to Skip Bittenbender, Donna R. Ching, Brent S. Sipes, Virginia Easton Smith, and Alan Teramura (University of Hawaii at Mānoa); Ray Baker (Lyon Arboretum), Tim Martin and Richard Loero (Kauai Coffee Co.), David W. Orr (Waimea Arboretum), Chifumi Nagai (Hawaii Agriculture Research Center), and George Staples (Bishop Museum) for their hospitality; and to Rosa Amelia Franqui and Evelio Hernández López (University of Puerto Rico). Thanks also to Ann Simpkins (USDA, ARS, Beltsville, MD) for excellent field assistance in Hawaii, Mexico, and Puerto Rico as well as her excellent work in our laboratory; to Cindy Park (formerly with USDA, ARS, Beltsville, MD) for teaching the senior author how to sequence and for invaluable laboratory support to MCA; to Carlos Quintero (Centro Nacional de Investigaciones de Café) for assistance in obtaining field samples in Colombia; and M. Greenstone (USDA) for comments on a previous version of this manuscript. We are grateful to Walter Gams (Centraalbureau voor Schimmelcultures, The Netherlands) for identifying endophytic Clonostachys rosea and Acremonium alternatum. The use of trade, firm, or corporation names in this publication is for the information and convenience of the reader. Such use does not constitute an official endorsement or approval by the United States Department of Agriculture or the Agricultural Research Service of any product or service to the exclusion of others that may be suitable.

\section{References}

Abdel-Baky, N.F., Abdel-Salam, A.H., 2003. Natural incidence of Cladosporium spp. as a biocontrol agent against whiteflies and aphids in Egypt. Journal of Applied Entomology 127, 228-235.

Akello, J.T., Dubois, T., Gold, C.S., Coyne, D., Nakavuma, J., Paparu, P., 2007. Beauveria bassiana (Balsamo) Vuillemin as an endophyte in 
tissue culture banana (Musa spp.). Journal of Invertebrate Pathology 96, 34-42.

Allee, L.L., Goettel, M.S., Gol'berg, A., Whitney, H.S., Roberts, D.W., 1990. Infection by Beauveria bassiana of Leptinotarsa decemlineata larvae as a consequence of fecal contamination of the integument following per os inoculation. Mycopathologia 111, 17-24.

An, Z.-Q., Siegel, M.R., Hollin, W., Tsai, H.-F., Schmidt, D., Schardl, C.L., 1993. Relationships among non-Acremonium sp. fungal endophytes in five grass species. Applied and Environmental Microbiology $59,1540-1548$.

Ananda, K., Sridhar, K.R., 2002. Diversity of endophytic fungi in the roots of mangrove species on the west coast of India. Canadian Journal of Microbiology 48, 871-878.

Arnold, A.E., Maynard, Z., Gilbert, G.S., 2001. Fungal endophytes in dicotyledonous neotropical trees: patterns of abundance and diversity. Mycological Research 105, 1502-1507.

Arnold, A.E., Lewis, L.C., 2005. Ecology and evolution of fungal endophytes, and their roles against insects. In: Vega, F.E., Blackwell, M. (Eds.), Insect-Fungal Associations: Ecology and Evolution. Oxford University Press, New York, pp. 74-96.

Barnett, H.L., Hunter, B.B., 1998. Illustrated Genera of Imperfect Fungi, fourth ed. APS Press, MN.

Barker, G.M., 1987. Mycorrhizal infection influences Acremoniuminduced resistance to Argentine stem weevil in grasses. Proceedings of the New Zealand Weed and Pest Control Conference 40, 199-203.

Bell, J.V., Hamalle, R.J., 1980. Heliothis zea larval mortality time from topical and per os dosages of Nomuraea rileyi conidia. Journal of Invertebrate Pathology 35, 182-185.

Bernardini, M., Carilli, A., Pacioni, G., Santurbano, B., 1975. Isolation of beauvericin from Paecilomyces fumoso-roseus. Phytochemistry 14, 1865.

Bills, G.F., Polishook, J.D., 1991. Microfungi from Carpinus caroliniana. Canadian Journal of Botany 69, 1477-1482.

Bing, L.A., Lewis, L.C., 1991. Suppression of Ostrinia nubilalis (Hübner) (Lepidoptera: Pyralidae) by endophytic Beauveria bassiana (Balsamo) Vuillemin. Environmental Entomology 20, 1207-1211.

Bing, L.A., Lewis, L.C., 1992a. Temporal relationships between Zea mays, Ostrinia nubilalis (Lep.: Pyralidae) and endophytic Beauveria bassiana. Entomophaga 37, 525-536.

Bing, L.A., Lewis, L.C., 1992b. Endophytic Beauveria bassiana (Balsamo) Vuillemin in corn: the influence of the plant growth stage and Ostrinia nubilalis (Hübner). Biocontrol Science and Technology 2, 39-47.

Bing, L.A., Lewis, L.C., 1993. Occurrence of the entomopathogen Beauveria bassiana (Balsamo) Vuillemin in different tillage regimes and in Zea mays L. and virulence towards Ostrinia nubilalis (Hübner). Agriculture Ecosystems \& Environment 45, 147-156.

Boonphong, S., Kittakoop, P., Isaka, M., Palittapongarnpim, P., Jaturapat, A., Danwisetkanjana, K., Tanticharoen, M., Thebtaranonth, Y., 2001. A new antimycobacterial, $3 b$-acetoxy-15a,22-dihydroxyhopane, from the insect pathogenic fungus Aschersonia tubulata. Planta Medica 67, 279-281.

Breen, J.P., 1994. Acremonium endophyte interactions with enhanced plant resistance to insects. Annual Review of Entomology 39, 401-423.

Broome, J.R., Sikorowski, P.P., Norment, B.R., 1976. A mechanism of pathogenicity of Beauveria bassiana on larvae of the imported fire ant, Solenopsis richteri. Journal of Invertebrate Pathology 28, 87-91.

Briggs, L.H., Fergus, B.J., Shannon, J.S., 1966. Chemistry of fungi-IV. Cyclodepsipeptides from a new species of Isaria. Tetrahedron Part 1 (Suppl. 8), 269-278.

Bultman, T.L., Borowicz, K.L., Schneble, R.M., Coudron, T.A., Bush, L.P., 1997. Effect of a fungal endophyte on the growth and survival of two Euplectrus parasitoids. Oikos 78, 170-176.

Bultman, T.L., Bell, G.D., 2003. Interaction between fungal endophytes and environmental stressors influences plant resistance to insects. Oikos 103, 182-190.

Bush, L.P., Wilkinson, H.H., Schardl, C.L., 1997. Bioprotective alkaloids of grass-fungal endophyte symbioses. Plant Physiology 114, 1-7.
Cammatti-Sartori, V., da Silva-Ribeiro, R.T., Valdebenito-Sanhueza, R.M., Pagnocca, F.C., Echeverrigaray, S., Azevedo, J.L., 2005. Endophytic yeasts and filamentous fungi associated with southern Brazilian apple (Malus domestica) orchards subjected to conventional, integrated or organic cultivation. Journal of Basic Microbiology 45, 397-402.

Cao, L.X., You, J.L., Zhou, S.N., 2002. Endophytic fungi from Musa acuminata leaves and roots in South China. World Journal of Microbiology \& Biotechnology 18, 169-171.

Castlebury, L.A., Sutherland, J.B., Tanner, L.A., Henderson, A.L., Cerniglia, C.E., 1999. Use of a bioassay to evaluate the toxicity of beauvericin to bacteria. World Journal of Microbiology \& Biotechnology 15, 119-121.

Champlin, F.R., Grula, E.A., 1979. Noninvolvement of beauvericin in the entomopathogenicity of Beauveria bassiana. Applied and Environmental Microbiology 37, 1122-1125.

Cherry, A.J., Lomer, C.J., Djegui, D., Shulthess, F., 1999. Pathogen incidence and their potential as microbial control agents in IPM of maize stem borers in West Africa. BioControl 44, 301-327.

Cherry, A.J., Banito, A., Djegui, D., Lomer, C., 2004. Suppression of the stem-borer Sesamia calamistis (Lepidoptera; Noctuidae) in maize following seed dressing, topical application and stem injection with African isolates of Beauveria bassiana. International Journal of Pest Management 50, 67-73.

Clark, C.L., Miller, J.D., Whitney, N.J., 1989. Toxicity of conifer needle endophytes to spruce budworm. Mycological Research 93, 508-512.

Clay, K., 1988. Fungal endophytes of grasses: a defensive mutualism between plants and fungi. Ecology 69, 10-16.

Clay, K., 1989. Clavicipitaceous endophytes of grasses: their potential as biocontrol agents. Mycological Research 92, 1-12.

Clay, K., Schardl, C., 2002. Evolutionary origins and ecological consequences of endophyte symbiosis with grasses. American Naturalist 160, S99-S127.

Clement, S.L., Kaiser, W.J., Eichenseer, H., 1994. Acremonium endophytes in germplasms of major grasses and their utilization for insect resistance. In: Bacon, C.W., White, J. (Eds.), Biotechnology of Endophytic Fungi of Grasses. CRC Press, Boca Raton, FL, pp. 185-199.

Clement, S.L., Elberson, L.R., Bosque-Pérez, N.A., Schotzko, D.J., 2005. Detrimental and neutral effects of wild barley-Neotyphodium fungal endophyte associations on insect survival. Entomologia Experimentalis et Applicata 114, 119-125.

De Bary, H.A., 1884. Vergleichende Morphologie und Biologie der Pilze Mycetozoen und Bacterien. Verlag von Wilhelm Engelmann, Leipzig.

Dingle, J., McGee, P.A., 2003. Some endophytic fungi reduce the density of pustules of Puccinia recondita f. sp. tritici in wheat. Mycological Research 107, 310-316.

Dugan, F.M., Lupien, S.L., 2002. Filamentous fungi quiescent in seeds and culm nodes of weedy and forage grass species endemic to the Palouse Region of Washington and Idaho. Mycopathologia 156, 3140.

Elmi, A.A., West, C.P., Robbins, R.T., Kirkpatrick, T.L., 2000. Endophyte effects on reproduction of a root-knot nematode (Meloidogyne marylandi) and osmotic adjustment in tall fescue. Grass and Forage Science 55, 166-172.

Evans, H.C., Holmes, K.A., Thomas, S.E., 2003. Endophytes and mycoparasites associated with an indigenous forest tree, Theobroma gileri, in Ecuador and a preliminary assessment of their potential as biocontrol agents of cocoa diseases. Mycological Progress 2, 149-160.

Fuller-Schaefer, C., Jung, K., Jaronski, S., 2005. Colonization of sugarbeet roots by entomopathogenic fungi. In: Proceedings of the 38th Annual Meeting of the Society for Invertebrate Pathology, Anchorage, Alaska, p. 49.

Funk, C.R., Halisky, P.M., Johnson, M.C., Siegel, M.R., Stewart, A.V., Ahmad, S., Hurley, R.H., Harvey, I.C., 1983. An endophytic fungus and resistance to sod webworms: association in Lolium perenne L.. Bio/Technology 1, 189-191. 
Ganley, R.J., Newcombe, G., 2005. Fungal endophytes in seeds and needles of Pinus monticola. Mycological Research 110, 318-327.

Gabriel, B.P., 1959. Fungus infection of insects via the alimentary tract. Journal of Invertebrate Pathology 1, 319-330.

Gardes, M., Bruns, T.D., 1993. ITS primers with enhanced specificity for basidiomycetes - application to the identification of mycorrhizae and rusts. Molecular Ecology 2, 113-118.

Gennaro, M., Gonthier, P., Nicolotti, G., 2003. Fungal endophytic communities in healthy and declining Quercus robur L. and $Q$. cerris L. trees in northern Italy. Journal of Phytopathology 151, 529-534.

Gillespie, A.T., Claydon, N., 1989. The use of entomogenous fungi for pest control and the role of toxins in pathogenesis. Pesticide Science 27, 203-215.

Glenn, A.E., Bacon, C.W., Price, R., Hanlin, R.T., 1996. Molecular phylogeny of Acremonium and its taxonomic implications. Mycologia $88,369-383$.

Gómez-Vidal, S., Lopez-Llorca, L.V., Jansson, H.-B., Salinas, J., 2006. Endophytic colonization of date palm (Phoenix dactylifera L.) leaves by entomopathogenic fungi. Micron 37, 624-632.

Grove, J.F., Pople, M., 1962. The insecticidal activity of beauvericin and the enniatin complex. Mycopathologia 70, 103-105.

Hajek, A.E., St. Leger, R.J., 1994. Interactions between fungal pathogens and insect hosts. Annual Review of Entomology 39, 293-322.

Hamill, R.L., Higgens, C.E., Boaz, H.E., Gorman, M., 1969. The structure of beauvericin, a new depsipeptide antibiotic to Artemia salina. Tetrahedron Letters 49, 4255-4258.

Humber, R.A., 1997. Fungi: Identification. In: Lacey, L.A. (Ed.), Manual of Techniques in Insect Pathology. Academic Press, London, pp. 153185.

Humber, R.A. 2007. Recent phylogenetically based reclassifications of fungal pathogens of invertebrates: Available from $<$ http://www. sipweb.org/>.

Inglis, G.D., Johnson, D.L., Goettel, M.S., 1996. Effect of bait substrate and formulation on infection of grasshopper nymphs by Beauveria bassiana. Biocontrol Science and Technology 6, 35-50.

Isaka, M., Tanticharoen, M., Thentaranonth, Y., 2000. Cordyanhydrides A and $\mathrm{B}$. Two unique anhydrides from the insect pathogenic fungus Cordyceps pseudomilitaris BCC 1620. Tetrahedron Letters 41, 16571660.

Jallow, M.F.A., Dugassa-Gobena, D., Vidal, S., 2004. Indirect interaction between and unspecialized endophytic fungus and a polyphagous moth. Basic and Applied Ecology 5, 183-191.

Jeffs, L.B., Khachatourians, G.G., 1997. Toxic properties of Beauveria pigments on erythrocyte membranes. Toxicon 35, 1351-1356.

Jegorov, A., Sedmera, P., Matha, V., Simek, P., Zahradničkova, Landa, Z., Eyal, J., 1994. Beauverolides L and La from Beauveria tenella and Paecilomyces fumosoroseus. Phytochemistry 37, 1301-1303.

Jones, K.D., 1994. Aspects of the biology and biological control of the European corn borer in North Carolina. Ph.D. thesis, Department of Entomology, North Carolina State University.

Kikuchi, H., Miyagawa, Y., Nakamura, K., Sahashi, Y., Inatomi, S., Oshima, Y., 2004. A novel carbon skeletal trichothecane, tenuipesine A, isolated from an entomopathogenic fungus, Paecilomyces tenuipes. Organic Letters 6, 4531-4533.

Kodaira, Y., 1962. Studies on the new toxic substances to insects, destruxin A and B, produced by Oospora destructor. Part I. Isolation and purification of destruxin A and B. Agricultural and Biological Chemistry 26, 36-42.

Krasnoff, S.B., Gupta, S., 1992. Efrapeptin production by Tolypocladium fungi (Deuteromycotina: Hyphomycetes). Intra- and inter-specific variation. Journal of Chemical Ecology 18, 1721-1741.

Krasnoff, S.B., Gupta, S., 1994. Identification of the antibiotic phomalactone from the entomopathogenic fungus, Hirsutella thompsonii var. synnematosa. Journal of Chemical Ecology 20, 293-302.

Krasnoff, S.B., Gibson, D.M., Belofsky, G.N., Gloer, K.B., Gloer, J.B., 1996. New destruxins from the entomopathogenic fungus Aschersonia sp.. Journal of Natural Products 59, 485-489.
Larran, S., Monaco, C., Alippi, H.E., 2001. Endophytic fungi in leaves of Lycopersicon esculentum Mill.. World Journal of Microbiology \& Biotechnology 17, 181-184.

Larran, S., Perello, A., Simon, M.R., Moreno, V., 2002a. Isolation and analysis of endophytic microorganisms in wheat (Triticum aestivum $\mathrm{L}$.) leaves. World Journal of Microbiology \& Biotechnology 18, 683-686.

Larran, S., Rollán, C., Bruno Angeles, H., Alippi, H.E., Urrutia, M.I., 2002 b. Endophytic fungi in healthy soybean leaves. Investigación Agraria: Producción y Protección de Vegetales 17, 173-177.

Leckie, B.M., 2002. Effects of Beauveria bassiana mycelia and metabolites incorporated into synthetic diet and fed to larval Helicoverpa zea, and detection of endophytic Beauveria bassiana in tomato plants using PCR and ITS. M.S. thesis, Department of Entomology, The University of Tennessee.

Lee, S.-Y., Nakajima, I., Ihara, F., Kinoshita, H., Nihira, T., 2005. Cultivation of entomopathogenic fungi for the search of antibacterial compounds. Mycopathologia 160, 321-325.

Lewis, L.C., Cossentine, J.E., 1986. Season long intraplant epizootics of entomopathogens, Beauveria bassiana and Nosema pyrausta, in a corn agroecosystem. Entomophaga 31, 36-69.

Lewis, L.C., Bing, L.A., 1991. Bacillus thuringiensis Berliner and Beauveria bassiana (Balsamo) Vuillemin for European corn borer control: program for immediate and season long suppression. Canadian Entomologist 123, 387-393.

Lewis, L.C., Berry, E.C., Obrycki, J.J., Bing, L.A., 1996. Aptness of insecticides (Bacillus thuringiensis and carbofuran) with endophytic Beauveria bassiana, in suppressing larval populations of the European corn borer. Agriculture Ecosystems \& Environment 57, 27-34.

Lewis, L.C., Bruck, D.J., Gunnarson, R.D., Bidne, K.G., 2001. Assessment of plant pathogenicity of endophytic Beauveria bassiana in $\mathrm{Bt}$ transgenic and non-transgenic corn. Crop Science 41, 1395-1400.

Liu, J.C., Boucias, D.G., Pendland, J.C., Liu, W.Z., Maruniak, J., 1996. The mode of action of hirsutellin A on eukaryotic cells. Journal of Invertebrate Pathology 67, 224-228.

Lomer, C.J., Cherry, A., Denis, D., 1997. Systemic Beauveria isolates for control of maize stem borers in Africa. In: Proceedings of the 30th Annual Meeting of the Society for Invertebrate Pathology, Banff, Canada, p. 44

Mazet, I., Hung, S.Y., Boucias, D.G., 1995. Hirsutellin A, a toxic protein produced in vitro by Hirsutella thompsonii. Journal of Invertebrate Pathology 64, 200-207.

Miller, J.D., MacKenzie, S., Foto, M., Adams, G.W., Findlay, J.A., 2002. Needles of white spruce inoculated with rugulosin-producing endophytes contain rugulosin reducing spruce budworm growth rate. Mycological Research 106, 471-479.

Okane, I., Nakagiri, A., Ito, T., 1998. Endophytic fungi in leaves of ericaceous plants. Canadian Journal of Botany 76, 657-663.

Omoto, C., McCoy, C.W., 1998. Toxicity of purified fungal toxin hirsutellin A to the citrus rust mite Phyllocoptruta oleivora (Ash.). Journal of Invertebrate Pathology 72, 319-322.

Ownley, B.H., Pereira, R.M., Klingeman, W.E., Quigley, N.B., Leckie, B.M., 2004. Beauveria bassiana, a dual purpose biocontrol organism, with activity against insect pests and plant pathogens. In: Lartey, R.T., Cesar, A.J. (Eds.), Emerging Concepts in Plant Health Management. Research Signpost, India, pp. 255-269.

Petrini, O., 1981. Endophytische Pilze in Epiphytischen Araceae, Bromeliaceae und Orchidiaceae. Sydowia 34, 135-148.

Pingel, R.L., Lewis, L.C., 1996. The fungus Beauveria bassiana (Balsamo) Vuillemin in a corn ecosystem: its effect on the insect predator Coleomegilla maculata De Geer. Biological Control 6, 137-141.

Pocasangre, L., Sikora, R.A., Vilich, V., Schuster, R.P., 2000. Survey of banana endophytic fungi from Central America and screening for biological control of the burrowing nematode (Radopholus similis). InfoMusa 9, 3-5.

Poprawski, T.J., Robert, P.-H., Maniania, N.K., 1985. Susceptibility of the onion maggot, Delia antiqua (Diptera: Anthomyiidae) to the mycotoxin destruxin E. Canadian Journal of Entomology 117, 801802 
Portilla, M., 2000. Desarrollo y evaluación de una dieta artificial para la cría de Hypothenemus hampei. Revista Colombiana de Entomología 26, 31-37.

Posada, F., Vega, F.E., 2005. Establishment of the fungal entomopathogen Beauveria bassiana (Ascomycota: Hypocreales) as an endophyte in cocoa seedlings (Theobroma cacao). Mycologia 97, 1195-1200.

Posada, F., Vega, F.E., 2006. Inoculation and colonization of coffee seedlings (Coffea arabica L.) with the fungal entomopathogen Beauveria bassiana (Ascomycota: Hypocreales). Mycoscience 47, 284-289.

Posada, F., Aime, M.C., Peterson, S.W., Rehner, S.A., Vega, F.E., 2007. Inoculation of coffee plants with the fungal entomopathogen Beauveria bassiana (Ascomycota: Hypocreales). Mycological Research 111, 749758.

Quesada-Moraga, E., Vey, A., 2004. Bassiacridin, a protein toxic for locusts secreted by the entomopathogenic fungus Beauveria bassiana. Mycology Research 108, 441-452.

Quesada-Moraga, E., Landa, B.B., Muñoz-Ledesma, J., Jiménez-Díaz, R.M., Santiago-Álvarez, C., 2006. Endophytic colonization of opium poppy, Papaver somniferum, by an entomopathogenic Beauveria bassiana strain. Mycopathologia 161, 323-329.

Rehner, S.A., Buckley, E.P., 2005. A Beauveria phylogeny inferred from nuclear ITS and EF1- $\alpha$ sequences: evidence for cryptic diversification and links to Cordyceps teleomorphs. Mycologia 97, 84-98.

Roberts, D.W., 1981. Toxins of entomopathogenic fungi. In: Burges, H.D. (Ed.), Microbial Control of Pests and Plant Disease 1970-1980. Academic Press, London, pp. 441-463.

Samson, R.A., 1974. Paecilomyces and some allied Hyphomycetes. Studies in Mycology 6, 1-119.

SAS Institute, Inc., 2001. An Introduction to the Analysis of Linear Mixed Models Using SAS Version 8.2. SAS Institute, Inc., Cary, NC.

Shields, M.S., Lingg, A.J., Heimsch, R.C., 1981. Identification of a Penicillium urticae metabolite which inhibits Beauveria bassiana. Journal of Invertebrate Pathology 38, 374-377.

St.-Germain, G., Summerbell, R., 1996. Identifying Filamentous Fungi: A Clinical Laboratory Handbook. Star Publishing Company, CA.

Steinhaus, E.A., 1949. Principles of Insect Pathology. McGraw-Hill Book Company, Inc., Toronto.

Strasser, H., Vey, A., Butt, T.M., 2000. Are there any risks in using entomopathogenic fungi for pest control, with particular reference to the bioactive metabolites of Metarhizium, Tolypocladium and Beauveria species? Biocontrol Science and Technology 10, 717-735.

Suryanarayanan, T.S., Kumaresan, V., Johnson, J.A., 1998. Foliar fungal endophytes from two species of the mangrove Rhizophora. Canadian Journal of Microbiology 44, 1003-1006.

Suryanarayanan, T.S., Senthilarasu, G., Muruganandam, V., 2000. Endophytic fungi from Cuscuta reflexa and its host plants. Fungal Diversity 4, 117-123.

Suryanarayanan, T.S., Wittlinger, S.K., Faeth, S.H., 2005. Endophytic fungi associated with cacti in Arizona. Mycological Research 109, 635639 .

Suzuki, A., Kanaoka, M., Isogai, A., Murakoshi, S., Ichinoe, M., Tamura, S., 1977. Bassianolide, a new insecticidal cyclodepsipeptide from
Beauveria bassiana and Verticillium lecanii. Tetrahedron Letters 25, 2167-2170.

Takeda, I., Guerrero, R., Bettucci, L., 2003. Endophytic fungi of twigs and leaves from Ilex paraguariensis in Brazil. Sydowia 55, 372-380.

Tian, X.L., Cao, L.X., Tan, H.M., Zeng, Q.G., Jia, Y.Y., Han, W.Q., Zhou, S.N., 2004. Study on the communities of endophytic fungi and endophytic actinomycetes from rice and their antipathogenic activities in vitro. World Journal of Microbiology \& Biotechnology 20, 303-309.

Vakili, N.G., 1990. Biocontrol of stalk rot in corn, pp. 87-105. In: Proceedings of the Forty-fourth Annual Corn and Sorghum Industry Research Conference, December 6-7, 1989, Chicago, IL. American Seed Trade Association, Washington, DC.

Vicari, M., Hatcher, P.E., Ayres, P.G., 2002. Combined effect of foliar and mycorrhizal endophytes on an insect herbivore. Ecology 83, 24522462.

Villacorta, A., 1985. Dieta meridica para criacao de sucessivas geracoes de Hypothenemus hampei Ferrari 1867 (Coleoptera: Scolytidae). Anais da Sociedade Entomológica do Brasil 14, 315-319.

Vining, L.C., Kelleher, W.J., Schwarting, A.E., 1962. Oosporein production by a strain of Beauveria bassiana originally identified as Amanita muscaria. Canadian Journal of Microbiology 8, 931-933.

Wagenar, M.M., Gibson, D.M., Clardy, J., 2002. Akanthomycin, a new antibiotic pyridone from the entomopathogenic fungus Akanthomyces gracilis. Organic Letters 4, 671-673.

Wagner, B.L., Lewis, L.C., 2000. Colonization of corn, Zea mays, by the entomopathogenic fungus Beauveria bassiana. Applied and Environmental Microbiology 66, 3468-3473.

Wainwright, M., Betts, R.P., Teale, D.M., 1986. Antibiotic activity of oosporein from Verticillium psalliotae. Transactions of the British Mycological Society 86, 168-170.

West, C.P., Izekor, E., Oosterhuis, D.M., Robbins, R.T., 1988. The effect of Acremonium coenophialum on the growth and nematode infestation of tall fescue. Plant Soil 112, 3-6.

White, J.F., Cole, G.T., 1986. Endophyte-host associations in forage grasses. V. Occurrence of fungal endophytes in certain species of Bromus and Poa. Mycologia 78, 852-856.

White, T.J., Bruns, T., Lee, S., Taylor, J., 1990. Amplification and direct sequencing of fungal ribosomal RNA genes for phylogenetics. In: Innis, M.A., Gelfand, D.H., Sninsky, J.J., White, T.J. (Eds.), PCR Protocols: A Guide to Methods and Applications. Academic Press, San Diego, pp. 315-322.

Wicklow, D.T., Roth, S., Deyrup, S.T., Gloer, J.B., 2005. A protective endophyte of maize: Acremonium zeae antibiotics inhibitory to Aspergillus flavus and Fusarium verticillioides. Mycological Research 109, 610-618.

Wilson, D., 1995. Endophyte: the evolution of a term, and clarification of its use and definition. Oikos 73, 274-276.

Žižka, J., Weiser, J., 1993. Effect of beauvericin, a toxic metabolite of Beauveria bassiana, on the ultrastructure of Culex pipiens autogenicus larvae. Cytobios 75, 13-19. 